\title{
State support for tourism clusters in green tourism
}

\author{
Sergey Yekimov ${ }^{1, *}$, Viktoriia Nianko ${ }^{2}$, Zhanna Chesnokova ${ }^{3}$, Lyudmila Dolmatova ${ }^{4}$, and \\ Anna Tkachenko ${ }^{5}$ \\ ${ }^{1}$ Publishing House “Education and Science” s.r.o., Olstynska 607/1, Praha 8, 18100, Czech Republic \\ ${ }^{2}$ Dniprovsk State Technical University ,Dnipropetrovsk region, Kamianske, Ukraine \\ ${ }^{3}$ Department of Economics and Management, Kamyshinsky Technological Institute \\ (branch) Volgograd State Technical University, Russia \\ ${ }^{4}$ Novocherkassk Engineering Institute reclamation, Novocherkassk, Russia \\ ${ }^{5}$ Siberian State University of Geosystem and Technologies, Novosibirsk, Russia
}

\begin{abstract}
Among the main areas that can improve rural infrastructure and change the economic and social situation in rural areas is green tourism. In many countries of the world, there is a tendency to increase the interest of citizens in recreation in rural areas. Tourists are attracted by the organic foods and a rural way of life.

However, in regions with active tourist activity, there are often many problems associated with causing damage to the environment. The desire to get the maximum profit can bring irreversible damage to nature.

Green tourism, in our opinion, requires coordination and regulation by state regulatory bodies. However, in our opinion, this should not hinder the entrepreneurial initiative.

In our opinion, state intervention is appropriate only when the interests of society and the industry require it. It is necessary to provide freedom of activity to the subjects of tourist activity in compliance with strict regulations.
\end{abstract}

\section{Introduction}

Agriculture in Ukraine currently faces a number of serious problems, the main of which are underemployment and unemployment, and the standard of living in rural areas is low compared to the city. The level of wages for employees of agricultural enterprises, as a rule, is lower than even for employees of industrial enterprises. Mass labor migration of the population from rural areas to cities.

In this regard, the priority is given to:

1. Improvement of living conditions, quality of public services and public utilities in rural areas.

2. Creating new jobs for rural residents.

3. Development of labor resources in rural areas, support of vocational education.

4. Complex solution of various socio-economic problems of rural regions.

\footnotetext{
*Corresponding author: 3701313@mail.ru
} 
5. Activation of innovation and investment activities in rural areas.

6. Development of transport infrastructure in rural areas.

In our opinion, green tourism is one of the areas that can change the socio-economic situation and improve the transport infrastructure in rural regions. All over the world, there is a tendency to increase the interest in recreation in rural areas. Tourists in rural areas are attracted to the rural lifestyle, organic food.

According to [1], in terms of its economic potential, green tourism can serve as a tool for improving the standard of living in rural areas, creating favorable conditions for business development in rural areas, and filling rural budgets.

According to [2], interest in recreation in rural areas has intensified as a result of increased pollution in cities.

According to [3], green tourism is an alternative agricultural activity for rural residents, based on the use of local human and natural resources, and contributes to the growth of employment and prevents the depopulation of rural areas.

In addition to increasing budget revenues, green tourism can stimulate the development of other sectors of the economy, such as trade, construction and transport.

According to [4], green tourism in many countries of the world is an integral component of the socio-economic development of rural regions.

According to [5], agro tourism in some countries accounts for up to $20 \%$ of the total income of the tourism industry. In the European Union, green tourism generates tens of billions of euros annually and is an important source of income for rural entrepreneurs and a source of regeneration and survival of rural areas.

According to [6], green tourism is currently the fastest growing segment of the tourism industry in many countries around the world.

The authors [7] identify the most common types of rural tourism (Figure 1):

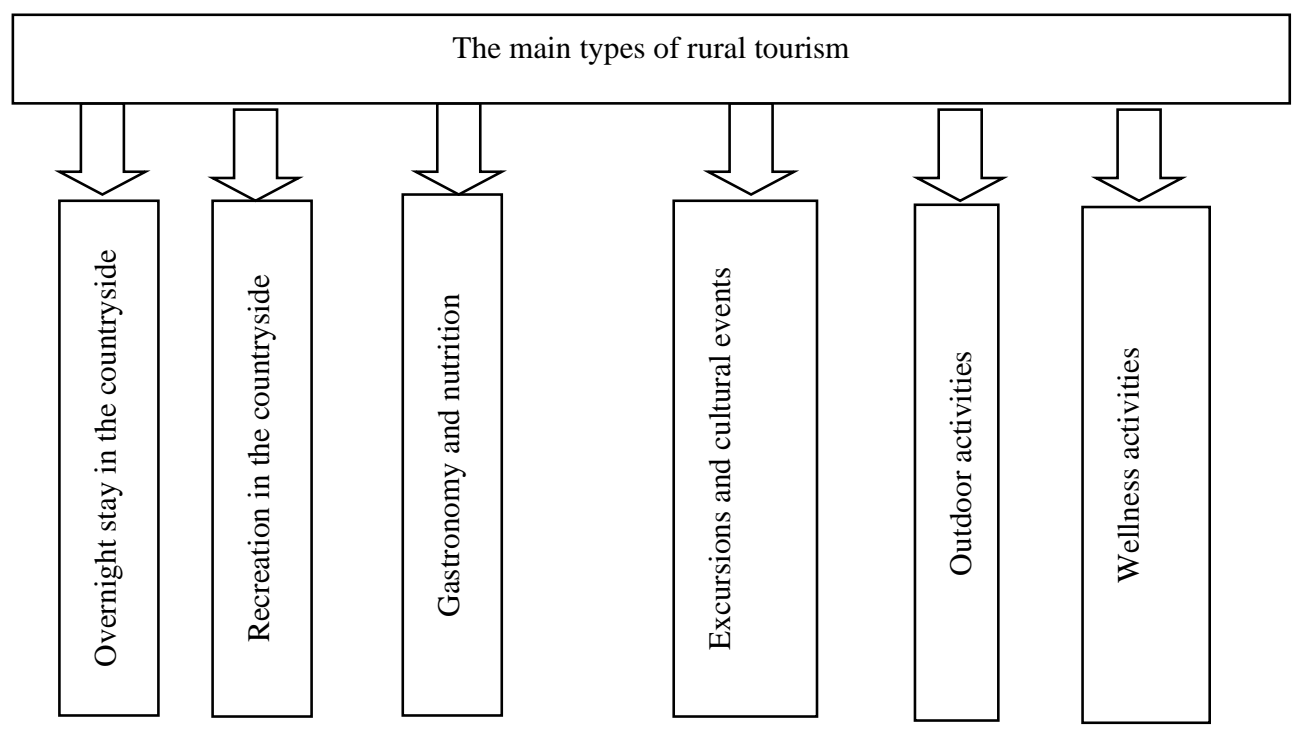

Fig. 1. The main types of rural tourism.

One of the directions of development of green tourism is based on the application of the cluster approach. 
According to [8], the cluster approach makes it possible to increase the economic efficiency and competitiveness of its member enterprises. A cluster is an open system, the composition of which may change over time.

According to [9], the cluster contributes to the favorable development of medium and small businesses that operate in a certain area and complement each other.

According to [10], the effectiveness of a cluster is determined by the synergistic effect of the parallel functioning of its participants.

According to [11], the cluster policy of the state should consist in creating favorable conditions for the functioning of clusters, information and methodological support for its participants.

According to [12], the tourist cluster should provide for the interaction of individual subjects of tourist activity, which include enterprises engaged in the production and sale of tourist products, as well as related activities.

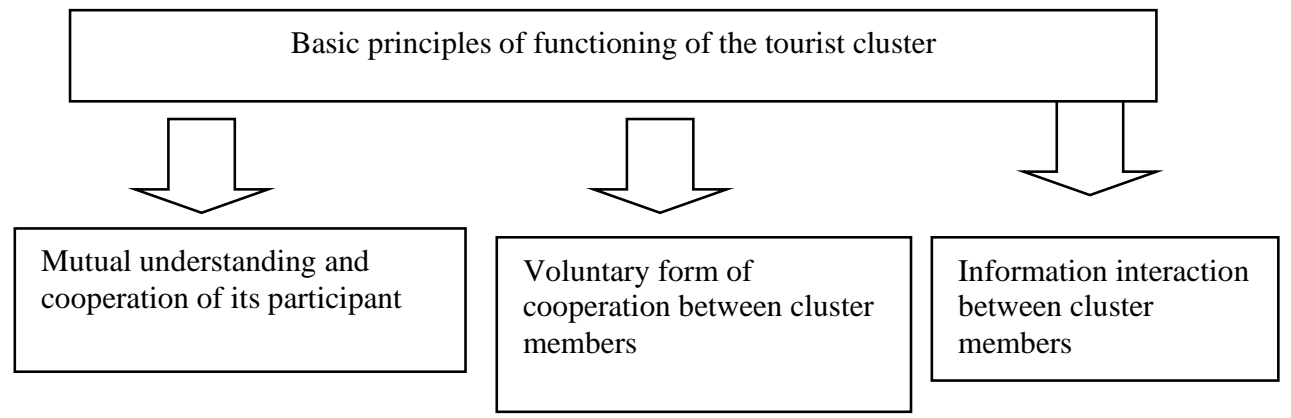

Fig. 2. Basic principles of functioning of the tourist cluster.

The authors [13] define a tourist cluster as an economic complex consisting of enterprises with different industry affiliations. They are united by joint activities aimed at meeting the needs of consumers regarding various types of active and passive recreation.

According to [14], the functioning of the tourism cluster should be based on the following basic principles (Figure 2).

According to [15], for the successful functioning of clusters, the following conditions must be met:

1) It is necessary to have interested people among the representatives of the authorities and entrepreneurs who are able to create and actually demonstrate the usefulness of the cluster for the region.

2) Information support between the cluster participants for the purpose of access to a highly qualified workforce and sales of products.

3) The interest of the participants in obtaining benefits from the existence of the cluster.

4) The existence of a regulatory framework that promotes the functioning and development of the cluster.

According to [16], the interest of local authorities in the existence of tourist clusters is to reduce the level of unemployment among the local population, increase budget revenues, improve regional transport infrastructure, and activate innovation and investment processes. Clusters can increase the competitiveness and economic potential of the region.

According to [17], the state should promote the training and retraining of specialists for cluster enterprises, conduct an antitrust policy, encourage investment and insure risks.

According to [18], the decision on the feasibility of creating a cluster should take into account that the tourist service consists of various complementary intangible and material services that are part of the tourist product. 
According to [19], cluster participants can achieve, through the synergistic effect of joint activities, an increase in the level of competitiveness, improved stability from the influence of adverse market factors, more efficient use of their opportunities, reduced credit and financial risks, increased labor productivity and reduced production costs.

According to [20], first of all, it is advisable to provide state support to economic sectors that are able to provide the maximum multiplier effect for the economy as a whole.

In our opinion, the main advantage of tourism is that it takes much more money to create a single job in the industry than it does to create a job in the tourism industry.

\section{Methods}

In carrying out this study, we used an analytical method, with the help of which we managed to study the problems in their unity and development.

Taking into account the goals and objectives of this study, we used a functional and structural method of carrying out scientific research.

This gave us the opportunity to consider some of the problems associated with the development of green tourism.

\section{Results}

Despite the success achieved, the process of creating tourist clusters in Ukraine is experiencing a number of difficulties, among which, in our opinion, the main ones are:

1) The imperfection of the existing regulatory documents that regulate the creation and functioning of tourist clusters;

2) Lack of adequate state financial support.

3) Lack of qualified specialists in the field of tourism.

4) Low investment attractiveness of the regions

5) The need for external coordination of the activities of enterprises included in the cluster;

6) Unsatisfactory performance of individual cluster participants reduces its overall effectiveness.

One of the most important factors influencing the development of green tourism is the environmental factor. It is he, in our opinion, to a greater extent determines to what extent the tourist will be satisfied with the tourist services provided to him.

In our opinion, such external factors as the level of unemployment and the level of income of the population have a great influence on the tourism sector. If the region is economically developed, it contributes to the development of tourism, improving the transport infrastructure and the material and technical base of the tourism industry enterprises.

Despite the importance that tourism has for the development of the region and the economy as a whole, it also generates a number of contradictions.

In regions with active tourist activity, there may be a number of problems associated with damage to nature. Often, the desire for maximum profit brings irreversible damage to the environment.

Based on the above analysis, the authors concluded that there is a need for a balanced state regulation of green tourism.

In our opinion, it is advisable to expand green tourism in Ukraine:

1. Further development of normative acts regulating the standardization of services in the field of rural tourism; 
2. Pay more attention to the training of specialists in the field of green tourism, including by state order and targeted applications from the regions;

3. Implementation of various regional projects to improve transport infrastructure in rural areas, improve the standard of living in rural areas with the involvement of local and state budgets, as well as funds from private investors.

4. Implementation of state monitoring of the implementation of state and regional programs for the development of rural tourism.

Green tourism allows you to use older people in the tourism business, this is very important, since they are more difficult to find employment than other categories of the working-age population.

Rural tourism helps to increase the income of rural residents and reduces the migration flow of labor resources from rural areas to the city, helps to reduce the level of social tension.

In our opinion, small farms are most interested in rural tourism, as the tourist service has a large added value.

In our opinion, to promote green tourism, training seminars should be held with the participation of interested rural residents. At these seminars, conduct master classes to create business plans, as well as produce relevant methodological literature.

We consider it expedient to create resource and information centers that would include information about the subjects of green tourism and the services they provide.

Modern information technologies make it possible to reduce the cost of information contacts and make information available to a large number of users.

Marketing communications should, in our opinion, be aimed at informing potential consumers about the tourist product and creating a positive image of the subjects of green tourism.

As a tool for attracting tourists in green tourism, we also suggest using virtual excursions, which allow a potential client to get an idea of the object of interest. At the same time, we understand that to create electronic content for virtual excursions, highly professional specialists are required, whose services for small green tourism entities will be very expensive. Given that rural tourism can play a major role in the development of the village, we see it appropriate to create specialized state studios for the development of content for virtual excursions.

In our opinion, educational activities aimed at promoting a healthy lifestyle and green tourism, as well as promoting tourist brands, are of great importance.

For the effective functioning of green tourism, in our opinion, the state should act as a coordinator between the various entities of the tourism industry and monitor compliance with legislation and environmental protection standards.

Rural tourism, in our opinion, is one of the most promising areas for the development of the agricultural sector of the Ukrainian economy. In addition to promoting a healthy lifestyle, this will contribute to the preservation of national spirituality and culture.

We believe that one of the most priority areas for overcoming the crisis in the agricultural sector of Ukraine is the activity in the field of green tourism.

This will allow us to systematically solve many socio-economic problems in rural areas.

\section{Discussion}

For the successful development of green tourism, in our opinion, it is necessary to ensure certain political, economic and legal conditions on the part of the state.

Without the absence of state regulation of the tourism industry, in our opinion, it is difficult to ensure its stable development, which would not have a negative impact on nature and objects of cultural and historical heritage. 
The state should develop and implement mechanisms that would, on the one hand, promote the attraction of tourists, and on the other hand, prevent the spontaneous development of the tourism industry, directing its evolution along the path that allows preserving the cultural and natural environment for future generations.

In our opinion, the state regulation of the tourism industry in the field of green tourism should provide (Figure 3):

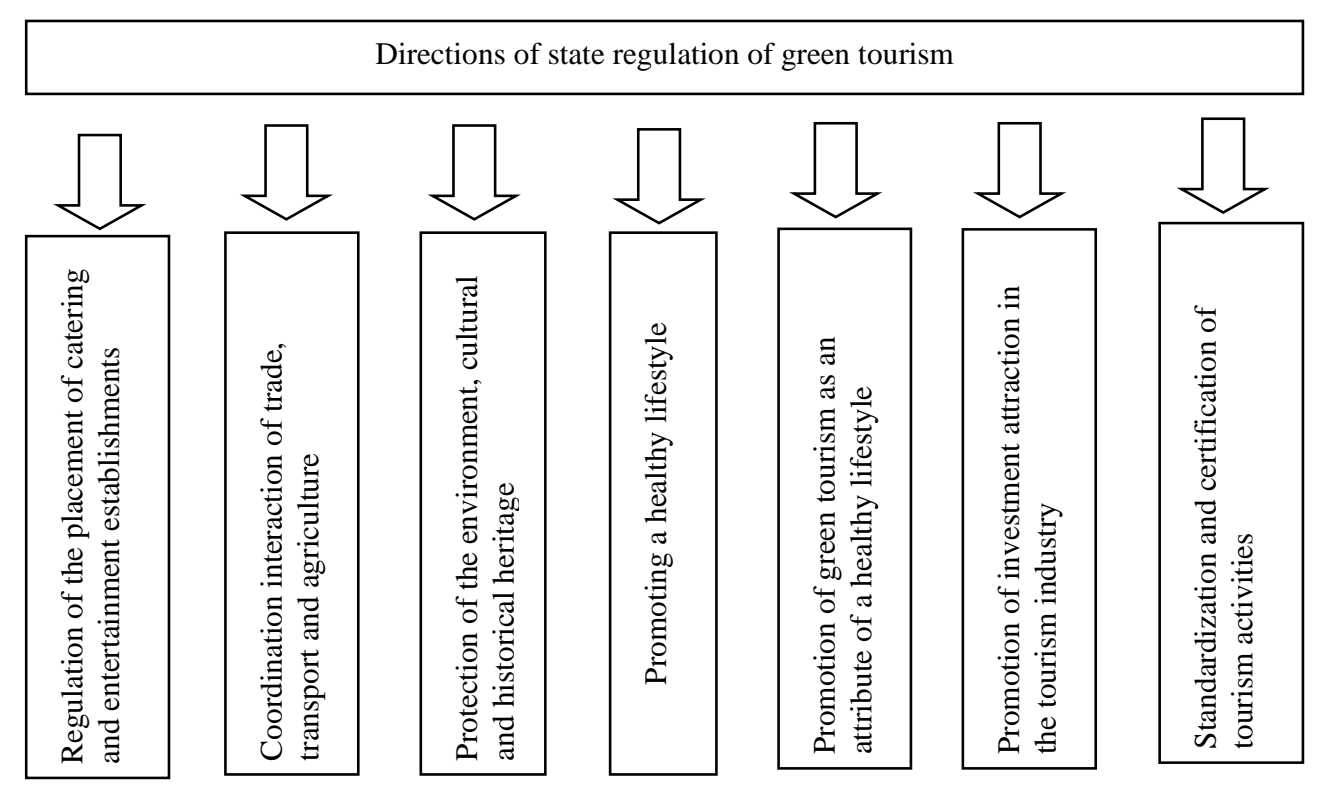

Fig. 3. Directions of state regulation of green tourism

Tourism, in our opinion, requires state regulation and coordination more than other sectors of the economy. At the same time, this should not hinder the entrepreneurial initiative. In our opinion, state intervention is appropriate only when the interests of society and the industry require it. It is necessary to provide freedom of activity to the subjects of tourist activity in compliance with strict regulations.

The tourism industry in many countries is one of the main sources of filling the state budget.

\section{Conclusions}

In our opinion, the development of green tourism requires a state strategy for the development of rural tourism. It should include the study of social and economic processes, as well as the integration of social, economic, environmental, and organizational subsystems to achieve the desired result.

Economic and social subsystems should reduce the level of unemployment in rural areas and improve the quality of material well-being of rural residents.

The task of the organizational subsystem is to create clusters and develop small businesses in the field of rural tourism.

It is very important that the process of implementing the development of rural tourism takes place in stages, taking into account the influence of external and internal factors. This, in our opinion, will allow us to achieve a stable development of the tourism industry and ensure the rational use of natural resources. 
Rural tourism, currently, in our opinion, can make it possible for small settlements to survive in modern conditions and reduce the unemployment rate in rural areas.

The experience of foreign countries shows that through green tourism, you can:

1) To bring a revival to the regional economy;

2) Improve the financing of environmental protection activities through additional resources;

3) Reduce the uneven development of individual regions.

4) Reduce migration flows and the level of unemployment in rural areas.

5) to Improve rural infrastructure.

6) Raise the standard of living in rural areas.

7) Get additional sales volumes of agricultural products

8) Domestic tourism, unlike foreign tourism, has a positive impact on the balance of payments of the state.

\section{References}

1. Pintassilgo, Pedro. (2015). Green tourism. 10.1007/978-3-319-01669-6_264-1.

2. Winarya, Sukma. (2017). KONSEP GREEN TOURISM DAN TREND GREEN TOURISM MARKETING (STUDI LITERATUR KAJIAN GREEN TOURISM DAN IMPLEMENTASINYA). 16. 47-53.

3. Boiko, Viktoriia. (2020). RURAL GREEN TOURISM IN UKRAINE: PROBLEMS AND PROSPECTS. Agrosvit. 58. 10.32702/2306-6792.2020.22.58.

4. Yarema, L.. (2020). PERSPECTIVE DEVELOPMENT OF RURAL GREEN TOURISM. Efektyvna ekonomika. 10.32702/2307-2105-2020.5.69.

5. Beteille, R.. (1996). Green tourism.

6. LOLUA, DAVID \& ALADASHVILI, MANANA. (2020). GREEN TOURISM - A CONTRIBUTING FACTOR TO THE DEVELOPMENT OF THE GREEN ECONOMY. Globalization and Business. 171-178. 10.35945/gb.2020.09.021.

7. Jones, Arwel. (1987). Green tourism. Tourism Management - TOURISM MANAGE. 8. 354-356. 10.1016/0261-5177(87)90095-1.

8. Diuk, A. \& Burlaka, N.. (2018). DEVELOPMENT OF GREEN TOURISM IN UKRAINE. Efektyvna ekonomika. 10.32702/2307-2105-2018.12.118.

9. Wei, Min \& Wei, Haixiang \& Huang, Haiyu. (2020). Evaluation system of green tourism industry. Tourism Analysis. 10.3727/108354220X15959893853848.

10. Ngo, Hao \& Van, Xuan \& University, Hien \& Minh, Ho \& Ai, Tran. (2021). Green tourism-sustainable tourism development in Phu Quoc Island district. 8. 25-30.

11. Meler, Marcel \& Ham, Marija. (2012). GREEN MARKETING FOR GREEN TOURISM. 10.13140/2.1.3701.5047.

12. Burlaka, N. \& Panko, V. \& Boiarska, Z.. (2020). PERSPECTIVES AND DEVELOPMENT OF AGRICULTURAL GREEN TOURISM IN VINNYTSIA REGION. Agrosvit. 61. 10.32702/2306-6792.2020.19-20.61.

13. Petrevska, Biljana \& Cingoski, Vlatko. (2017). Branding the Green Tourism in Macedonia. Sociology and Space. 55. 101-116. 10.5673/sip.55.1.5.

14. Pokalchuk, Mykhailo \& Korniienko, Anhelina. (2017). ON THE ISSUE OF RURAL GREEN TOURISM. 10.25313/2520-2308-2020-10-6430.

15. DIACHYNSKA, Olena. (2020). FEATURES OF GREEN TOURISM DEVELOPMENT IN VINNYTSIA REGION. ECONOMY FINANCES 
MANAGEMENT Topical issues of science and practical activity. 35-43. 10.37128/2411-4413-2019-3-4.

16. Shcherbachenko, Viktoriia \& Zakharkina, Liudmyla \& Zakharkin, Oleksii \& Basantsov, Ihor. (2021). Green tourism as innovative direction of households' activities in rural areas. E3S Web of Conferences. 234. 00005. 10.1051/e3sconf/202123400005.

17. Plotnikova, Mariia. (2018). GREEN TOURISM DEVELOPMENT IN SMART COMMUNITIES. Baltic Journal of Economic Studies. 4. 203-210. 10.30525/22560742/2018-4-3-203-210.

18. Zbarsky, Vasyl \& Hrybova, Diana. (2020). MODELING OF FORMS OF GREEN TOURISM DEVELOPMENT UKRAINE. Economic scope. 10.32782/22246282/159-8.

19. Orellana, Edyth \& Araujo, Juan \& Villao, José. (2021). GREEN TOURISM \& ADVENTURE.

20. Gibson, Dawn. (2014). Green tourism alleviating poverty.

21. Plotnikova, Mariia. (2018). GREEN TOURISM DEVELOPMENT IN SMART COMMUNITIES. Baltic Journal of Economic Studies. 4. 203-210. 10.30525/22560742/2018-4-3-203-210. 